Nukmatus Syahria: The Use of Indonesia Traditional Game to Upgrade Pupils Speaking...

\title{
THE USE OF INDONESIA TRADITIONAL GAME TO UPGRADE PUPILS SPEAKING SKILLS AND LESSEN PUPILS SPEAKING ANXIETY
}

\author{
Penggunaan Permainan Tradisional Indonesia untuk Meningkatkan Keterampilan Berbicara \\ Siswa dan Mengurangi Kecemasan Berbicara Siswa \\ Nukmatus Syahria \\ Universitas PGRI Adi Buana Surabaya \\ Campus I: Jln. Ngagel Dadi III-3B/37 Surabaya 60245 Jawa Timur, Indonesia \\ Campus II: JIn. Dukuh Menanggal XII, Surabaya 60234 Jawa Timur, Indonesia \\ Email: syahria@unipasby.ac.id
}

Date received: 16 May 2020; approved: 9 October 2020; Final Revision: 23 December 2020

\begin{abstract}
This article examine the effectiveness of Indonesia traditional game, engklek, to upgrade the pupils speaking skills and to minimize the pupils speaking anxiety. The study found that games have several of disadvantages. One of the game are not appropriate to be applied in the upper level (adult) because some of them consider that games are bothering. Other study claims that games give several kinds of advantages in the teaching and learning activities and it is suitable to be applied for any level of age. The clashing research findings from both studies lead the researcher's curiosity to investigate the effectiveness of Indonesia traditional game to boost university pupils speaking skills. The designs adopt in this study are experimental design and descriptive design. The results showed that the treatment given to the experimental group (engklek game) is able to give an impact to increase the score of pupils speaking skills that is higher than the control group (presentation technique). The majority of the pupils agree that engklek game is effective to upgrade the pupils speaking fluency, lessen the pupils anxiety, and boost the pupils motivation, cognitive and social skills.
\end{abstract}

Keywords: effectiveness, engklek game, speaking skills, speaking anxiety.

\begin{abstract}
Abstrak
Penelitian ini menguji keefektifan permainan tradisional Indonesia, engklek, untuk meningkatkan keterampilan berbicara siswa dan mengurangi kecemasan berbicara siswa. Salah satu penelitian menemukan bahwa permainan memiliki beberapa kekurangan, salah satunya yaitu permainan tidak seharusnya diterapkan di level atas (dewasa) karena beberapa di antaranya menganggap hal tersebut tersebut mengganggu dan merepotkan. Dalam penelitian lain, dinyatakan bahwa permainan menawarkan beberapa macam keunggulan dalam kegiatan belajar mengajar dan cocok untuk diterapkan di segala tingkatan usia. Temuan penelitian yang saling bertabrakan dari kedua studi tersebut mendorong rasa keingintahuan peneliti untuk menyelidiki keefektifan permainan tradisional Indonesia dalam meningkatkan kemampuan berbicara para mahasiswa. Penelitian ini mengadopsi desain eksperimental dan desain deskriptif. Hasil penelitian menunjukkan bahwa perlakuan yang diberikan kepada kelompok eksperimen (engklek) mampu memberikan dampak peningkatan pada skor speaking siswa yang lebih tinggi dibandingkan kelompok kontrol (teknik presentasi). Mayoritas siswa setuju bahwa permainan engklek efektif untuk meningkatkan kefasihan berbicara siswa, mengurangi kecemasan siswa, dan meningkatkan motivasi, keterampilan kognitif, dan sosial siswa.
\end{abstract}

Kata kunci: efektivitas, permainan Engklek, keterampilan berbicara, kecemasan berbicara

\section{PRELIMINARY}

Speaking has crucial functions outside the classroom. Therefore, those who have mastered English speaking ability have more chance to obtain jobs in many companies. Baker and Westrup (2003) state 
Nukmatus Syahria: The Use of Indonesia Traditional Game to Upgrade Pupils Speaking...

that pupils who speak English fluently can have larger opportunity for having better jobs and receiving promotion.

For native speakers, speaking is likely to be a trouble-free process, but for many non-native English speakers, it is a complicated process. It needs high requisite on apprehension when foreign language speech is being processed (Hughes, 2010).

Even though the use of English is popular among Indonesian people but in the reality there are still many Indonesian pupils strive with the use of English, especially during speaking. Most of them cannot speaks very well. They are likely to be shy and feel anxious during speaking in the public. However, speaking skills is needed to be mastered by both first and second language speaker (Nunan, 1995).

To be able to obtain the speaking proficiency, it needs more than grammatical and vocabulary mastery. Speaking skills is also determined by several kinds of affective factors such as self-confidence, mindset, motivation and anxiety (Krashen, 1982; Arnold, 2005; Henter, 2014). Oxford (1990) adds that the biggest influence on pupils success and failure in speaking performance is the pupils affective factors.

The problems that often experience by the foreign language learners in conducting English speaking is probably caused by cognitive or psychological factors. Learners with a good cognitive competence may have a problem on speaking. This is caused by main psychological factors such as motivation, self-esteem, and anxiety are potential aspects which influence the learners' oral performance (Aouatef, 2015). The psychological factors such as the feeling of being worried when committing errors, having less confidence and less motivation to initiate talks, being shy to utter their ideas as well as being anxious during speaking in front of the class (Juhana, 2012). These kinds of behavior may appear because of less opportunity for the learners to practice speaking up in front of public and because the teacher often do error correction in front of their classmates during their speaking performance (Fauzan, 2014).

Moreover, MacIntyre (1999) highlights that language anxiety gives impact in the process of language learning by intervening the pupils input cognitive processes, processing, and output level. Shao et al (2013) add in the input level, language anxiety may negatively impact pupils language learning potential and capacity, such as anxious students who are excessively concerned regarding the negative evaluations turn to have their attention distracted. Instead of paying attention on the receiving information, their attention is distracted as they attempt to seek the way out to lessen people's negative evaluations, which is actually not related to their language task.

In the processing level, language anxiety intervening by restraining the pupils speed and accuracy in keeping the information (Horwitz et al., 1986), causing pupils less successful than others (Broidy, 2005). Thus, it is arduous for the pupils to memorize new vocabulary when they feel anxious during speaking. Furthermore, in the output level, language anxiety impacts the quality of pupils oral production skills. According to (King, 2013; MacIntyre, 2007), anxious pupils quickly become shy and speechless, or simply unwilling to participate in oral activities even when they can speak up and likely to refuse when given a chance to speak. Therefore, it is obvious that anxious pupils are likely to show slower performance than those who are more calm and able to manage with foreign language anxiety (Fallah, 2016).

Dealing with the pupils motivation, Öztürk and Gürbüz (2014) investigate the factors that caused anxiety for pupils in learning speaking as well as the effect of anxiety on target language communication. The result indicated that pupils feeling of stress and anxious can hinder their language mastery and performance abilities. The researcher highlights that the higher the anxiety the lower the pupils speaking performance. Furthermore, Putri (2014) has performed a research on the correspondence between anxiety and the pupils speaking performance. The result exhibits a significant positive correspondence between low anxiety score obtained by the pupils and their speaking performance as well as significant negative correspondence between the pupils who obtain high anxie- 
Nukmatus Syahria: The Use of Indonesia Traditional Game to Upgrade Pupils Speaking...

ty score and their speaking performance. This is to say that, psychological factors are dominant in affecting the pupils oral performance in negative ways.

The educators must be aware of those psychological factors being mentioned above and they have to be able to figure out this situation otherwise the pupils will have a difficulty to obtain their speaking skills and to optimize their speaking performance. Teaching and learning of speaking must be meaningful and fun to encourage the pupils to participate actively and to lessen the pupils anxious feelings (Baer and Kaufman, 2012).

Indonesian traditional games can be applied in teaching speaking. It will help to give the sparks in the teaching and learning activities and it will help to elevate the pupils motivation in learning.

By playing games, pupils are motivated to communicate actively each other and it will support them to speak more fluent and helps to develop their vocabularies (Azar, 2012). Zhonggen (2019) reports that educational games are advantageous for pupils to raise their cognitive competence, to boost the positive impact of learning, to add the pupils mood in learning, to raise the pupils confidence and creativity as well as to boost their cooperative skills. Moreover, several studies on traditional gamebased learning show that traditional games can also develop pupils social skills and boost pupils cooperative skills (Kasim, 2017; Handayani, 2017; Kamal, 2016; Silonde, 2013). Gozcu and Caganaga (2016) add that games can develop pupils comprehension in oral and written of English. This is because games help the pupils to develop their structure as well as their pronunciation. Based on the study of Hung, Sun, and Yu, 2015; Miller, 2015), the relevant game integration with the curriculum can ameliorate pupils motivation and help to maximize the learning outcomes.

According to Achroni (2012), traditional games bring several kinds of advantages to the players. Several of benefits are mentioned as follows.

First, traditional games can preserve our tradition. Indonesia traditional games are associated to the culture of its origin. Games taught the moral and cultural val- ues of its origin which is important to shape one's personality and it can influence one's mindset or action through the songs that consist of folktales or historical stories. As in Cublak Cublak Suweng games in which the players are asked to sing the traditional song from Java that the lyrics in the song contain moral and philosophical value of Javanese customs that teach us about simplicity and for not being attach too much on the worldly things. Thus, traditional games can maintain the values which are substantial in our cultures, can make us appreciate more on our culture and they can also provide a better understanding toward our belonging and identity.

Second, traditional games help in promoting social skills. There are various kinds of Indonesia traditional games that involve group play, such as dakon, engklek and bentengan. These games will stimulate interaction and socialization. In addition of the togetherness, we are taught to obey rules, taking turns, and also solidarity in play. This kind of social interaction will contribute to the social emotional development as it trains us to cooperate well with others, to handle our emotions well, and helps in developing our patient as we are taught to wait for the turn to play and to be sportive in playing.

Third, traditional games help to improve one's health. Traditional games usually incorporate a lot of physical activities which can improve our physical health. For example, a traditional Indonesian game called Gobak Sodor that involves two groups in which each group is consist of 3 to 5 persons who try to run around the field to break through the defensive line. This game will stimulate motor and muscle development, train dexterity and at the same time, it will train coordination with fellow groups and apply tactics to achieve victory.

Fourth, traditional games help in developing the mother tongue. Most of the Indonesia traditional games are likely to involve the language of their origin, such as Jamuran games in which the players are asked to chant. The players will be able to promote their mother tongue through chanting and they can develop their verbal 
Nukmatus Syahria: The Use of Indonesia Traditional Game to Upgrade Pupils Speaking...

skill because in this game they are asked to construct a new phrase. By using this game, teacher can modify the game by using the target language (English) to help in progressing the pupils verbal skills.

At last, traditional games can help to flourish the social bonds. Indonesia traditional games support the interaction among each other and it can be applied in any kinds of age or expertise. That interaction let us recognize each other much better and develop social bonds that may be difficult to create in the digital age.

However, from the preliminary study done by the researcher in several campus in Surabaya, Indonesia, not many of the educators in high education level apply games in their teaching and learning activities because games are considered childish and quite annoying for adults. As Stojkovic and Jerotijevic (2011) claim that games have several disadvantages. Firstly, it deals with the discipline issue because when pupils play with games they tend to be riots. Secondly, when the games do not have adequate instruction, it will confuse the pupils. Thirdly, if the pupils are already familiar with the games, they may get bored with it. And finally, games are not appropriate to be applied in the upper level (adult) because some of them found that games are bothering.

Mubaraq, Hermaniar, and Palupi (2019) point that games provide several kinds of advantages. Games can encourage pupils to be more motivated in the learning activities. Educational games helps to promote critical thinking, problem solving, and imagination. Educational games also provide immediate feedback for the educators and pupils. It suggest fresh, different and dynamic mode of teaching that can substitute the traditional worksheets and can be applied for any levels of age.

Based on research findings regarding the application of games in the upper level of education, this research would like to investigate the effectiveness of traditional games in advancing the pupils speaking skills in the university level. The research problem were formulated as follow;

1. Is there any significant difference students who taught by using traditional games with students who taught by using presentation technique in teaching Speaking?

2. How do the students view the application of engklek games in teaching speaking?

\section{RESEARCH METHOD}

The design used in this study was quantitative study. The quantitative study adopts experimental design and descriptive design. To start the treatment, the researcher classified the participants into two groups; 35 participants in class $A$ and 37 participants in Class B. Class A were treated by using presentation technique while Class $B$ were trained by using traditional games, engklek. The participants of the study were the university students who took the preintermediate speaking course during the beginning of the semester.

The engklek games were adopted from traditional games from Riau, Indonesia called engklek. Engklek is a traditional game in which the players jump on a flat square drawn on the ground. They have to jump with one foot from one box to the next until finish. This game is usually done in group by boys and girls. The researcher put several of questions in the squares that each of the players has to answer and if they can answer they can jump to the next square until they reach the finish line. However, if they cannot answer the questions, they will be punished and has to start the games from the beginning. The engklek games (engklek) has three kinds of boxes style, namely aeroplane box, mount box and propeller box. The following is the examples of the boxes.

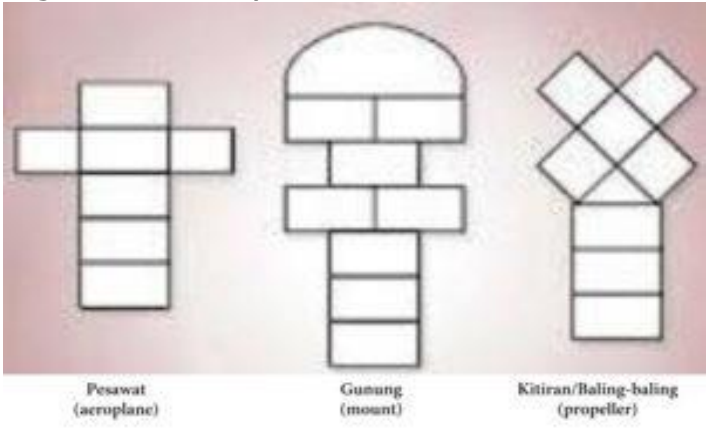

Researcher started this treatment after the mid test, because the result was not really good. The researcher conducted the study 
Nukmatus Syahria: The Use of Indonesia Traditional Game to Upgrade Pupils Speaking...

for two months during the odd semester at one of the universities in Surabaya. Before mid test, researcher conducted the usual lesson for speaking, thematic lesson.

The instruments used in this study were the speaking test, close-ended questionnaire as well as hand phone. The hand phone is used to record pupils activities during the engklek games application to see the pupils progress on their banks of vocabulary as well as to give possibility for the pupils to see their mistakes during speaking while doing the engklek games. The video recorded from hand phone was used to support the results from the questionnaire, to complement and triangulate the findings.

The questionnaire was distributed after the implementation of the engklek game to 37 pupils of Pre-Intermediate speaking class. There were ten questions with four options of responses (Extremely agree, Agree, Uncertain, Disagree). The pupils points of views were carefully examined. Each of the items in the questionnaire was calculated and described in a form of percentage to find out the pupils view in the utilization of engklek game. The aim of the study is to discover whether traditional games technique can upgrade the pupils speaking skills as well as to identify the students' view regarding the implementation of the engklek games. To maintain bias on the results of the study, the researcher invited two raters who are senior lecturers in the researcher's university. The raters were given the scoring rubric to measure the pupils performance during the test.

The engklek game was implemented within six meetings. The rest of the meetings, six meetings, were used for the pupils to practice their speaking in thematic Speaking lesson.

\section{RESULT AND ANALYSIS}

3.1 Is there any significant difference students who taught by using traditional games with students who taught by using presentation technique in teaching Speaking?

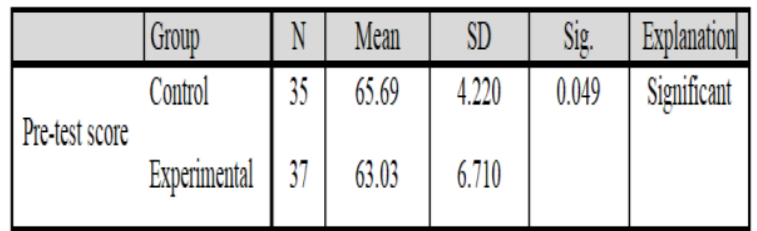

Table 1.Pre-test Score

The test results on the pre-test scores between the control group and the experimental group obtained an average score of the control group $(M=65.69, S D=4.22)$, the experimental group $(M=63.03, S D=$ 6.71 ) and the significance value of 0.049 $(p<0.05)$, so it can be seen that there are significant differences between the two groups. This means that before the research was conducted, the condition of the two groups to be tested had different speaking abilities, therefore the researcher tested the hypothesis using the difference score data of the pre-test and post-test or called gain score.

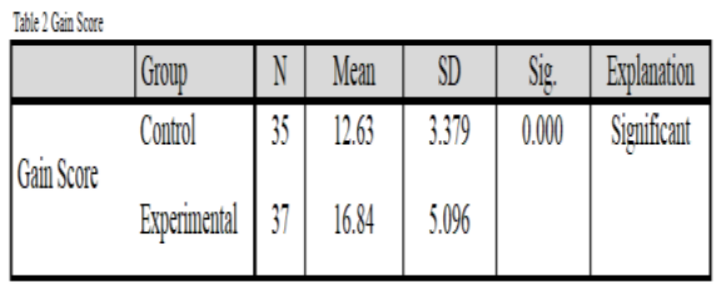

The test results on the gain score between the control group and the experimental group obtained an average score of the control group $(M=12.63, S D=3.38)$ and the experimental group $(M=16.84, S D=$ $5.10)$ while the significance value of 0.000 $(p<0.05)$ so it can be seen that there is a significant difference between the two groups, meaning that the treatment given to the experimental group (engklek games) is able to give an impact to increase the score of the pupils speaking skills that is higher than the control group (presentation technique).

The outcome obtained from the traditional games applied in teaching speaking in this study is in accordance with the study from Gozcu and Caganaga (2016) who claims that games is proven to help foster the pupils comprehension in oral and written of English. The pupils oral production in the experimental group showed a lot of improvements. Pupils who used to be 
Nukmatus Syahria: The Use of Indonesia Traditional Game to Upgrade Pupils Speaking...

very timid in initiating the conversation, keep silent when their turn to speak is coming as well as who had a difficulty in expressing their ideas orally, after the application of engklek (Engklek) games turned into more enthusiastic in learning speaking and they become more confident in expressing themselves orally.

During the discussion session, the pupils become more active and their vocabulary began to develop. Several of the pupils who used to answer the questions using the complex sentence, such as my mom likes to cook simple food for breakfast, began to shift to use the complex compound sentence, for instance; though my mom prefers cooking simple food for breakfast, she made us special chicken curry with broccoli cheese mashed potato, and we enjoyed it very much.

During the application of the game, the timid pupils who used to sit at the back during the Speaking class, offered themselves to be the first turn in playing the engklek game even though sometime during the game when they had to answer the questions that need long answers, their speech were still stuck in the middle but their motivation to initiate the talks were increased and they tried to use the fillers such as, umm, I guess, I think, well, when they forgot or do not know about the meaning of one or two words in English. In this stage, their classmates are sincerely to help them by prompting them, "what do you mean?", "try to use another sentence", do you mean...?" After their classmate prompted them, these timid pupils began to know and to remember the words. These activities help to build pupils cooperative and social skills. The relaxing and joyful situation in the speaking class helps the timid pupils to overcome their speaking anxiety and they often do not aware that they are actually being assessed by the lecturers during the implementation of the game.

3.2. How do the students view the implementation of engklek games in teaching speaking?

The following table showed the calculation of the questionnaire distributed to $37 \mathrm{pu}$ pils of Pre-Intermediate speaking;
Table 3. Result of pupils questionnaire

\begin{tabular}{|c|c|c|c|c|c|c|c|c|c|}
\hline \multirow{2}{*}{$\begin{array}{l}\mathbf{N} \\
\mathbf{0}\end{array}$} & \multirow{2}{*}{ Items } & \multicolumn{4}{|c|}{ Score } & \multicolumn{4}{|c|}{ Percentage } \\
\hline & & 1 & 2 & 3 & 4 & 1 & 2 & 3 & 4 \\
\hline $\begin{array}{c}X \\
1\end{array}$ & $\begin{array}{l}\text { Engklek } \\
\text { game is a } \\
\text { fun and } \\
\text { creative way } \\
\text { to learn } \\
\text { speaking }\end{array}$ & $\begin{array}{l}1 \\
7\end{array}$ & 24 & 4 & 1 & $\begin{array}{l}46 \\
\%\end{array}$ & $\begin{array}{l}65 \\
\%\end{array}$ & $\begin{array}{c}1 \\
1 \\
\%\end{array}$ & $\begin{array}{l}3 \\
\%\end{array}$ \\
\hline $\begin{array}{l}x \\
2\end{array}$ & $\begin{array}{l}\text { Engklek } \\
\text { game helps } \\
\text { the students } \\
\text { to reduce } \\
\text { their bore- } \\
\text { dom in the } \\
\text { speaking } \\
\text { lesson }\end{array}$ & 9 & 27 & 0 & 1 & $\begin{array}{l}24 \\
\%\end{array}$ & $\begin{array}{l}73 \\
\%\end{array}$ & $\begin{array}{c}0 \\
\%\end{array}$ & $\begin{array}{l}3 \\
\%\end{array}$ \\
\hline $\begin{array}{l}x \\
3\end{array}$ & $\begin{array}{l}\text { Engklek } \\
\text { game can } \\
\text { help the } \\
\text { students to } \\
\text { foster speak- } \\
\text { ing fluency } \\
\end{array}$ & $\begin{array}{l}1 \\
1\end{array}$ & 26 & 0 & 0 & $\begin{array}{l}30 \\
\%\end{array}$ & $\begin{array}{l}70 \\
\%\end{array}$ & $\begin{array}{c}0 \\
\%\end{array}$ & $\begin{array}{l}0 \\
\%\end{array}$ \\
\hline $\begin{array}{l}X \\
4\end{array}$ & $\begin{array}{l}\text { Engklek } \\
\text { game helps } \\
\text { the students } \\
\text { to enrich } \\
\text { their vocabu- } \\
\text { lary }\end{array}$ & $\begin{array}{l}1 \\
7\end{array}$ & 20 & 0 & 0 & $\begin{array}{l}46 \\
\%\end{array}$ & $\begin{array}{l}54 \\
\%\end{array}$ & $\begin{array}{c}0 \\
\%\end{array}$ & $\begin{array}{l}0 \\
\%\end{array}$ \\
\hline $\begin{array}{l}X \\
5\end{array}$ & $\begin{array}{l}\text { Engklek } \\
\text { games helps } \\
\text { the students } \\
\text { to promote } \\
\text { their pronun- } \\
\text { ciation }\end{array}$ & $\begin{array}{l}1 \\
4\end{array}$ & 20 & 3 & 0 & $\begin{array}{l}38 \\
\%\end{array}$ & $\begin{array}{l}54 \\
\%\end{array}$ & $\begin{array}{c}8 \\
\%\end{array}$ & $\begin{array}{l}0 \\
\%\end{array}$ \\
\hline $\begin{array}{l}X \\
6\end{array}$ & $\begin{array}{l}\text { Engklek } \\
\text { game helps } \\
\text { to maintain } \\
\text { students' } \\
\text { social skills } \\
\end{array}$ & $\begin{array}{l}2 \\
8\end{array}$ & 9 & 0 & 0 & $\begin{array}{l}76 \\
\%\end{array}$ & $\begin{array}{l}24 \\
\%\end{array}$ & $\begin{array}{c}0 \\
\%\end{array}$ & $\begin{array}{l}0 \\
\%\end{array}$ \\
\hline $\begin{array}{l}x \\
7\end{array}$ & $\begin{array}{l}\text { Engklek } \\
\text { game give a } \\
\text { new nuance } \\
\text { in learning } \\
\text { Speaking } \\
\end{array}$ & $\begin{array}{l}1 \\
9\end{array}$ & 17 & 1 & 0 & $\begin{array}{l}51 \\
\%\end{array}$ & $\begin{array}{l}46 \\
\%\end{array}$ & $\begin{array}{c}3 \\
\%\end{array}$ & $\begin{array}{l}0 \\
\%\end{array}$ \\
\hline $\begin{array}{l}X \\
8\end{array}$ & $\begin{array}{l}\text { Engklek } \\
\text { game reduce } \\
\text { the students' } \\
\text { anxiety and } \\
\text { arouse the } \\
\text { students' } \\
\text { initiative to } \\
\text { speak } \\
\end{array}$ & 9 & 26 & 2 & 0 & $\begin{array}{l}24 \\
\%\end{array}$ & $\begin{array}{l}70 \\
\%\end{array}$ & $\begin{array}{c}5 \\
\%\end{array}$ & $\begin{array}{l}0 \\
\%\end{array}$ \\
\hline $\begin{array}{l}X \\
9\end{array}$ & $\begin{array}{l}\text { Engklek } \\
\text { game helps } \\
\text { to elevate } \\
\text { students' } \\
\text { motivation }\end{array}$ & $\begin{array}{l}1 \\
7\end{array}$ & 19 & 1 & 0 & $\begin{array}{l}46 \\
\%\end{array}$ & $\begin{array}{l}51 \\
\%\end{array}$ & $\begin{array}{c}3 \\
\%\end{array}$ & $\begin{array}{l}0 \\
\%\end{array}$ \\
\hline $\begin{array}{l}\mathrm{X} \\
1 \\
0\end{array}$ & \begin{tabular}{|l}
\multicolumn{2}{c}{ Engklek } \\
game helps \\
to improve \\
students' \\
cognitive \\
skills \\
\end{tabular} & $\begin{array}{l}1 \\
4\end{array}$ & 23 & 0 & 0 & $\begin{array}{l}38 \\
\%\end{array}$ & $\begin{array}{l}62 \\
\%\end{array}$ & $\begin{array}{c}0 \\
\%\end{array}$ & $\begin{array}{l}0 \\
\%\end{array}$ \\
\hline
\end{tabular}

Description:

1: Extremely agree 2: Agree 3: Uncertain 4: Disagree 
Nukmatus Syahria: The Use of Indonesia Traditional Game to Upgrade Pupils Speaking...

In the attempt to develop pupils speaking skills, engklek game is effective to foster the pupils speaking fluency $(70 \%)$, enrich the pupils vocabulary (54\%) and promote the pupils pronunciation (54\%). The result of the video recording complemented the results of the questionnaire. Based on the results of the video recording, the pupils vocabularies were increased compared to their vocabulary before the engklek games were applied. They began to use the synonym words during the application of the engklek game, for instance instead of saying like they change it into fond of, happy $\rightarrow$ joyful, hardworking $\rightarrow$ industrious, come $\rightarrow$ arrive, bring $\rightarrow$ carry, go $\rightarrow$ travel, beautiful $\rightarrow$ attractive, disturb $\rightarrow$ annoy, start $\rightarrow$ begin, boring $\rightarrow$ dull, big $\rightarrow$ enormous, important $\rightarrow$ essential, not enough $\rightarrow$ insufficient, tell $\rightarrow$ inform, many/a lot of $\rightarrow$ numerous, choose $\rightarrow$ select.

The pupils pronunciation were also developed because in this game they were asked to do the tongue twister and recited some poems whenever they were punished because they cannot answer the questions from the lecturers or they were run out of time in answering the questions. The enjoyable situation during the implementation of the game made the pupils forgot that they are assessed during the game. From the video recording, the pupils talks with the lecturers and their peers were running smoothly and the pupils felt relax when they have to deliver their notions in their speech. These findings is in line with the finding from Azar (2012) who points out that by playing games, pupils are motivated to communicate actively each other thus it will support them to speak more fluent and develop their vocabularies.

The engklek game that has been modified by the researcher, in this case accommodates the pupils to learn speaking more effectively as well as helps to promote the pupils intention and strengthen their confidence to learn speaking. It can be seen from table 3 that $70 \%$ of the pupils agree that engklek game helps to reduce their speaking anxiety and raise their initiative to speak while $73 \%$ of them agree that engklek game can help to reduce their boredom during the Speaking lesson. Ac- cording to the pupils, they like the implementation of engklek games because they feel relax even though they have to answer several questions from the lecturers. The ambience of the class is also different with the usual speaking class. The fun nuance in the speaking activity makes the pupils forget their tense and anxious feeling during speaking in public. Therefore, the findings met with the finding from Baer and Kaufman, 2012 who notes that teaching and learning of speaking must be meaningful and fun to encourage the pupils to participate actively and to lessen the pupils anxious feelings. $75 \%$ of the pupils agree that engklek game is a fun way to learn Speaking and $51 \%$ of them strongly agree that Engklek game gives a new nuance in learning Speaking. The pupils often need to move around instead of sitting down like the usual speaking class during the games application. This makes the pupils become active physically and mentally.

The questions from the lecturers were varied, and there were some punishments for those whose dice went out from the box. The punishments are like reciting tongue twister and poems or singing an English song. These kinds of variations in the Speaking activities make the pupils mood in learning Speaking increased. $51 \%$ of the pupils agree that they became more motivated in the Speaking lesson and $62 \%$ of the pupils cognitive skills were improved as the result that they have to answer several sets of problem solving questions. This outcome is parallel with the finding from Zhonggen (2019) who reports that educational games are advantageous for pupils to raise their cognitive competence, to boost the positive impact of learning, to add the pupils mood in learning, to raise the pupils confidence and creativity as well as to boost their cooperative skills. And the findings are also in line with the study of Hung, Sun, and Yu, 2015 and Miller ,2015 who state that the relevant game integration with the curriculum can ameliorate pupils motivation and help to maximize the learning outcomes.

During the application of the game the pupils were separated in a group, so they have to cooperate well with their teams to win the game. This at the same time helps 
Nukmatus Syahria: The Use of Indonesia Traditional Game to Upgrade Pupils Speaking...

to boost the pupils cooperative skills and $76 \%$ helps to cultivate the pupils social skills, in which in the modern games are rarely be found. The outcome is parallel with the study from (Kasim, 2017; Handayani, 2017; Kamal, 2016; Silonde , 2013) who state that traditional games can also develop pupils social skills and boost their cooperative skills.

Engklek games is able to provide a new nuance for the pupils in learning speaking and help them to upgrade their speaking performance. It is proven that engklek games is effective to be applied for all level of education. It is not only suitable to be applied for the young learners but also for the university level. This outcome is in line with the study of Mubaraq, Hermaniar, and Palupi (2019) who claim that games give several kinds of advantages, namely games can encourage pupils to be more motivated in the learning activities, educational games helps to promote critical thinking, problem solving, and imagination, educational games provide immediate feedback for the educators and pupils, educational games suggest fresh, different and dynamic mode of teaching that can substitute the traditional worksheets and it can be applied for distinctive levels of age.

However, this study also has some limitations. The researcher did not provide detail explanation regarding how to play the game therefore sometime the pupils confuse about what to do after one round to the other round. For the efficiency of time and in order to add more joy and the pupils motivation, the researcher must also pay attention on the variations of speaking activities as well as the questions being applied in the game.

\section{CONCLUSION}

The application of Indonesia traditional games, such as engklek games can be one of the alternatives which can be considered by the educators for teaching speaking. Indonesia is rich with various kinds of traditional games, such as padhang bulan, dakon, gobak sodor, petak umpet and so forth, in which the educator can try to apply them in their speaking activities to help the pupils to acquire their speaking skills, to improve the pupils cognitive and social skills as well as to motivate them in learning speaking.

The utilization of Indonesia traditional games is not only fun but it will also help to maintain Indonesia's cultural heritage so that the new generation can still pass it to the next generation so their existences will not be extinct. Indonesia traditional games is also useful to lift up the mental and physical of the youth because most of them requires the players to move a lot, to practice the coordination of hands, feet and eyes, teach the players to be patient to wait for their turn to play and also teach them for not cheating during the play, because to win the game is not the main thing. The most important thing is that they have to be able to cooperate well and to keep the togetherness among the members in the team.

In order to help the pupils to develop their speaking performance, according to Brinton (2012), English language educators must require knowledge of the aspects they are going to teach, a recognition of the potential problems that the pupils may experience, as well as a target for administering pedagogical concern (what to teach and what to assess for the pupils).

Moreover, the language educators must also need to be mindful of the various kinds of pupils motivations as well as pupils characteristics and how they may impact the interaction in the classroom. Affective factors, learners' abilities, motivation, personality, age, pupils learning style, pupils cultural backgrounds, learning beliefs, and pupils attitudes can all impact the pupils speaking fluency as well as pupils speaking performance. Those differences will impact on learning, but they are not features of learning that a teacher can control (Thanesh, 2013). Teachers should become facilitators of a smooth and fluent conversation experiences that pupils will have.

The more concerned pupils in the activities and the more stimuli that the pupils receive, the more they will participate and become fluent in speaking. In this case, relaxing and fun atmosphere plays a key role in helping the pupils to achieve their success in the speaking performance. Therefore, it is very necessary for the language educators to apply the engaging and 
Nukmatus Syahria: The Use of Indonesia Traditional Game to Upgrade Pupils Speaking...

fun activities in the Speaking lesson. Traditional games can be one of the options. For further research, the researcher can try to examine for the effectiveness of another Indonesian traditional games in helping the students to obtain other language skills (reading, writing, listening) or to master other language components (vocabulary, grammar, pronunciation).

Seeing the facts that Indonesia traditional games bring many advantages to the players, therefore it is expected that the educators applied them in their teaching and learning activities so that the young generation will not only know about playing with gadgets and PC but they will also can feel the joy of playing the traditional games. The parents can also start to familiarize their children with Indonesia traditional games, because they are very unique and they are parts of the identity of Indonesian people. To make the youth more interested with the traditional games, the educators can create an online game that contains Indonesia traditional games.

\section{BIBLIOGRAPHY}

Achroni, K. (2012). Mengoptimalkan Tumbuh Kembang Anak Melalui Permainan Tradisional. Yogyakarta: Jevalitera.

Azar, Ali Sorayaie. (2012). "The Effect of Games on EFL Learners Vocabulary Learning Strategies." International Journal Of Basic and Applied Science 01(02).

Aouatef, Belegdair. (2015). The Main Psychological Factors Affecting Learners' Oral Performance. Case Study: Second Year LMD Students of English. Mohamed Kheider University of Birska. http://dspace.univbiskra.dz:8080/jspui/bi tstream/123456789/5962/1/BELEGDAIR \%20Aouatef.pdf, accesed December 28 2019 19:07 P.M

Baker, J., \& Westrup, H. (2003). Essential Speaking Skills: A Handbook for English Language Teachers. London: Continuum.
Baer, J., and J. C. Kaufman. (2012). Being Creative Inside and Outside the Classroom, How to Boost Your Students' Creativity-and Your Own. The Netherlands: Sense Publishers.

Brinton, D. M. (2012). " Content-Based Instruction in English for Specific Purposes," The Encyclopedia of Applied Linguistics. doi:10.1002/9781405198431.wbeal0191

Fauzan, Umar. (2014). "The Use of Improvisation Technique to Improve the Speaking Ability of EFL Students," Dinamika IImu 14(2).

Gozcu, Emine, and Cagda Kivanc Caganaga. (2016). "The Importance of Using Games in EFL Classrooms," Cypriot Journal of Educational Sciences, 11(3), page 126- 135

Henter, R. (2014). "Affective factors involved in learning a foreing language," Procedia - Social and Behavioral Sciences, 127, page 373-378.

Handayani, P. (2017). "Upaya Peningkatan Keterampilan Sosial Siswa Melalui Permainan Tradisional Congklak Pada Mata Pelajaran IPS," Premiere Educandum Jurnal Pendidikan Dasar Dan Pembelajaran 7(1), page 39-46.

Hung, CY, CJY Sun, and PT Yu. (2015). "The Benefits of a Challenge: Student Motivation and Flow Experience in Tablet- PC-Game-Based Learning," Interactive Learning Environments, 23(2), page 172-90.

Juhana. (2012). "Psychological Factors That Hinders Students from Speaking in English Class (A Case Study in a Senior High School in South Tangerang, Banten, Indonesia)," Journal of Education and Practice, 3 (12).

Krashen, Stephen. (1982). "Acquiring a Second Language," World Englishes, Vol 1 Issue 3, page 97-101.

Kamal, M. (2016). "Penerapan Permainan 
Nukmatus Syahria: The Use of Indonesia Traditional Game to Upgrade Pupils Speaking...

Tradisional 'Manjalo' Sebagai Upaya Menumbuhkan Keterampilan Sosial Anak Sejak Dini," Jurnal Educative: Journal of Education Studies, 1(1), page 72-80.

\section{Kasim, S. (2017). "Pengembangan Panduan Permainan Tradisional Bugis- Makassar Dalam Meningkatkan Keterampilan Sosial Siswa," Jurnal Psikologi Pendidikan \& Konseling, 3(1), page 45-52.}

Miller, A. (2015). "Games Centered Approaches in Teaching Children \& Adolescents: Systematic Review of Associated Student Outcomes," Journal of Teaching in Physical Education, 34(1), page 36-58.

Mubaraq, Yasyir Fahmi, Yulieda Hermaniar, and Tri Winindyasari Palupi. 2019. "Teachers' Role in HAndling Multicultural Classroom : Overview on Teaching Strategies and Media," ELT-Echo 4(1), page 25-35.

Nunan, D. (1995). Language Teaching Methodology. New York: Prentice Hall.

Oxford, R. L. (1990). Language learning strategies: What every teacher should know. New York: Newbury House Publishers

Öztürk\&Gurbuz. (2014). "Speaking anxiety among Turkish EFL learners: The case at a state university," Journal of Language and Linguistics Studies, 10(101), page 117.

Silonde, D. P. (2013). "Model Bimbingan Kelompok Berbasis Nilai Budaya Suku Tolaki Untuk Meningkatkan Keterampilan Sosial Siswa," Jurnal Bimbingan Konseling UNNES , 2(2), page 64-70.

Stojkovi, Miljana K., and Danica M. Jeroti. (2011). "Reasons for Using or Avoiding Games in an EFL Classroom," 1st International Conference on Foreign Language Teaching and Applied Linguistics page 940-47.

Thanesh, U. (2013). "Testing oral skills: An innovative approach to promote fluency," Language in India, 13 (3), page 381-390.

Zhonggen, Yu. (2019). "A Meta-Analysis of Use of Serious Games in Education over a Decade," International Journal of Computer Games Technology, 2019 (3). 